\title{
Antibacterial Activity of Alcoholic and Aqueous Extracts of Agaricus bisporus Against Food Borne Bacterial Pathogens
}

\author{
Alyaa Razooqi Hussein*, Eman Mohammed Ali and Ebtehal Hamid \\ Department of Biology, College of Science, University of Baghdad, Baghdad-Iraq. \\ Corresponding Author: alyatiba@yahoo.co.uk.
}

\begin{abstract}
Two extracts of $50 \mathrm{mg} \cdot \mathrm{ml}^{-1}$ Agaricus bisporus alcoholic and aqueous were used in order to study their effect against two pathogenic bacteria. Salmonella typhi and Staphylococcus aureus strains isolated from chicken and minced meat samples respectively, then identified according to biochemical tests. Antibacterial activity of Agaricus bisporus extracts (alcoholic and aqueous) was studied by agar well diffusion method. The results exhibited that aqueous mushroom extract has no effect against the two tested bacteria, while alcoholic extract of mushroom affect against the two tested bacteria and the effect against $S$. aureus was more than that against Salmonella typhi and the zone of inhibition was $15 \mathrm{~mm}$ and $9 \mathrm{~mm}$ respectively. The ethanol alcohol $96 \%$ and water were used as control. From this study, mushroom extracts especially ethanolic or alcoholic could be used to control the transmission of pathogenic bacteria from food. [DOI: 10.22401/JUNS.21.1.17]
\end{abstract}

Keywords: Agaricus bisporus, Antibacterial activity, Alcoholic \& Aqueous extracts, Foodborne bacterial pathogens.

\section{Introduction}

Recently, human pathogenic micro organisms have developed numerous drug resistance due to unselective and random use of antimicrobial agents that frequently used in the treatment of infectious diseases. This state required researchers for examining cheaper and easily available antimicrobial stuffs from various sources which are the good sources of novel antimicrobial chemotherapeutic agents [1].

Agaricus bisporus white button mushroom is a worldwide fungus with a distinguishing maturing body that is widely cultivated in the world, it includes both edible and non edible species, some mushroom serve as food because of their nutrient materials while the other have been used extensively in traditional medication [2].

Edible mushroom characteristically contain many different bio active compounds such as glycolipids, polysaccharides, sesquiterpenes etc., with miscellaneous biological activities such as anticancer, antibacterial, antifungal and antiviral agents. Investigators presented antimicrobial activity of several mushrooms [3] extracted from mycelia and fruiting bodies of various mushrooms have been reported for antimicrobial action against wide range of infective bacteria [4].
In modern years, a number of studies were conducted in various countries to govern the prospective therapeutic properties of mushrooms. [5,6] described bioactivities from mushrooms include antioxidant, antifungal, antibacterial, and antiviral properties.

This study was aimed to control food poisoning pathogenic bacteria by using alcoholic and aqueous Agaricus bisporus extracts.

\section{Materials and Methods}

Agaricus bisporus fruiting bodies were obtined from mycology laboratory in biology department, College of Science, University of Baghdad.

\section{Isolation and identification of pathogenic bacteria from food samples}

Ten food samples were used for isolation of pathogenic bacteria, five of which hash meat and the other five from chicken meat samples. Five grams of each sample were suspended in $45 \mathrm{ml}$ of D.W, $0.1 \mathrm{ml}$ of each suspension put in the bottom of Petri- dish and poured the suitable medium by pouring plate method.

Salmonella Shigella agar (ss agar) and Mannitol Salt agar were used for isolation of pathogenic bacteria. The incubation of plates were at $37^{\circ} \mathrm{C}$ for $24 \mathrm{hr}$. Biochemical tests were used for identification of the isolates. 
Preparation of mushroom crude extracts[ Reid et al.,[7]

Fresh mushrooms were divided into thin slices and dried for 7days in sun, then dried mushrooms were minced using an electrical mincer, the minced mushroom was mixed with $15 \mathrm{ml}$ of cold distilled water, absolute ethanol $(99 \%)$ in $50 \mathrm{ml}$ tubes. Samples were placed in shaker incubator for $24 \mathrm{hr}$. at $150 \mathrm{rpm}$ and $25^{\circ} \mathrm{C}$. The extracts of hot water were got by boiling the mushrooms in $15 \mathrm{ml}$ of distilled water for $10 \mathrm{~m}$ and then permiting the suspension to cool at room temperature. Suspensions were then clarified using filter paper type Whatman no. 1, dried under cold air and re-formed to $50 \mathrm{mg} \cdot \mathrm{ml}^{-1}$ in sterile DW for water extracts or dimethyl sulfoxide DMSO for the other extracts (ethanol).

Screening for antibacterial activity of Agaricus bisporus extracts

An agar well diffusion method[8] was used for screening of mushroom extracts (ethanol \& water) of Agaricus bisporus against the isolated bacteria, Mueller Hinton agar medium was used during this examination. Mueller Hinton agar medium was autoclaved at $121.6^{\circ} \mathrm{C}$ for 30 minutes and poured into Petri dishes. Bacteria were grown in Brain Heart infusion broth for $24 \mathrm{hr}$. The overnight culture suspensions were adjusted by comparing alongside with 0.5 McFarland turbidity standard tubes. A $100 \mu 1$ of bacterial suspension was spread by sterile swabs on each Mueller Hinton agar plates. Four agar wells of $8 \mathrm{~mm}$ diameter were prepared with the help of sterilized stainless steel cork borer in each Petri plate. Wells in each plate were loaded with $100 \mu \mathrm{l}$ of prepared extracts (ethanol and water) of Agaricus bisporus. The control well containing pure ethanol and water only. The plates were incubated at $37^{\circ} \mathrm{C}$ for $24 \mathrm{hr}$ in the incubator. The zones of inhibition were measured as the diameter of the inhibition around the wells (in $\mathrm{mm}$ ) including the well diameter using a ruler.

\section{Results and Discussion}

Isolation and identification of pathogenic bacteria of food sample

Two pathogenic bacteria were isolated from food samples, one of which Staphylococcus aureus isolated from hash meat and the other was Salmonella typhi that isolated from chicken meat. The biochemical test and microscopical examination confirmed this result. The biochemical tests that used in identification of $S$. aureus catalase test positive, beta hemolysis on blood agar, on mannitol salt agar appeared yellow colonies as shown in Fig.(1). In microscopical examination appeard $\mathrm{G}+\mathrm{ve}$ cocci arranged in clusters.

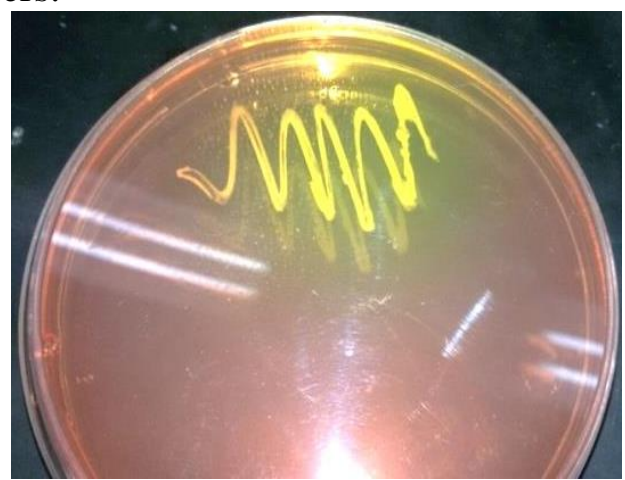

Fig.(1): Staphylococcus aureus yellow colonies on mannitol salt agar.

Salmonella G-ve, short bacilli, when grown on S.S agar (Salmonella, Shigella agar) appeared as black colonies as shown in Fig.(2).

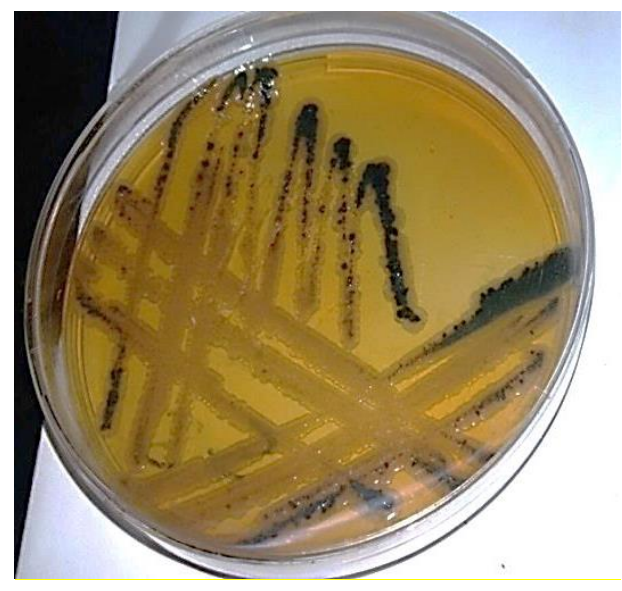

\section{Fig.(2): Salmonella typhi black colonies on SS agar.}

Antibacterial activity of Agaricus bisporus Extracts against $S$. aureus and $S$. typhi

Agaricus bisporus Ethanolic \& water extracts were verified against S.typhi \&S. aureus. An agar well diffusion method was used to prove anti-bacterial activity of extracts of Agaricus bisporus against food borne pathogenic bacteria.

Results showed that ethanolic extract of Agaricus bisporus exhibited antibacterial 
activity against both pathogenic bacteria (S.typhi and S.aurens) and the effect against Staphylococcus. aureus was more than that of Salmonella .typhi. The diameter of inhibition zone was $15 \mathrm{~mm}$ against S.aureus and $9 \mathrm{~mm}$ against S.typhi as shown in Table (1) and Fig.(3) and (4).

Table (1)

Antibacterial activity of $A$. bisporus ethanolic and aqueous extracts against two food borne bacteria.

\begin{tabular}{|c|c|c|c|c|}
\hline M. O. & $\begin{array}{l}\text { Ethanol } \\
\text { Extract }\end{array}$ & $\begin{array}{c}\text { Aqueous } \\
\text { Extract }\end{array}$ & $\begin{array}{c}\text { Control } \\
\text { Water }\end{array}$ & $\begin{array}{c}\text { Control } \\
\text { Ethanol }\end{array}$ \\
\hline $\begin{array}{c}\text { S. } \\
\text { aureus }\end{array}$ & $\begin{array}{c}\text { No } \\
\text { growth } \\
+++ \\
15 \mathrm{~mm} \\
\end{array}$ & $\begin{array}{c}\text { growth } \\
-\end{array}$ & $\begin{array}{c}\text { growth } \\
-\end{array}$ & $\begin{array}{c}\text { growth } \\
-\end{array}$ \\
\hline S.typhi & $\begin{array}{c}\text { No } \\
\text { growth } \\
+9 \mathrm{~mm} \\
\end{array}$ & $\begin{array}{c}\text { growth } \\
-\end{array}$ & $\begin{array}{c}\text { growth } \\
-\end{array}$ & $\begin{array}{c}\text { growth } \\
-\end{array}$ \\
\hline
\end{tabular}

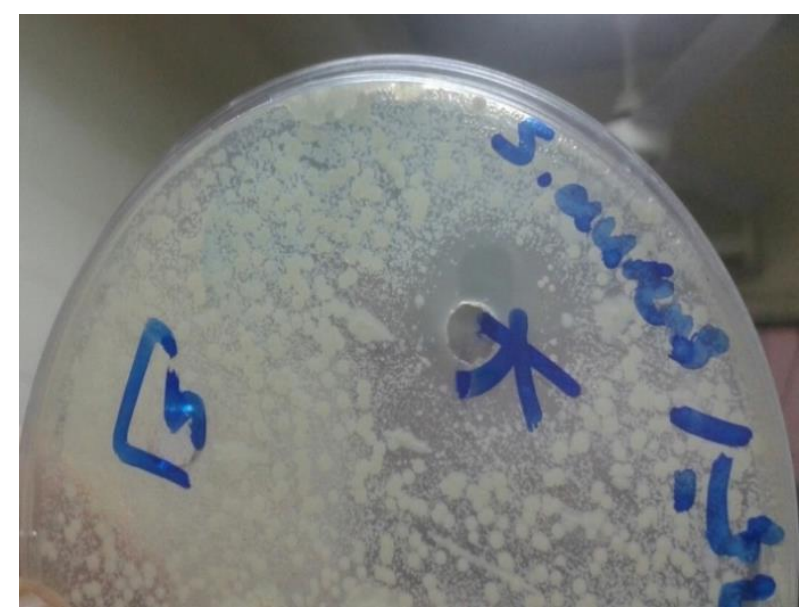

Fig.(3): Antibacterial activity of alcohol extract of Agaricus bisporus against Staphyllococcus aureus.

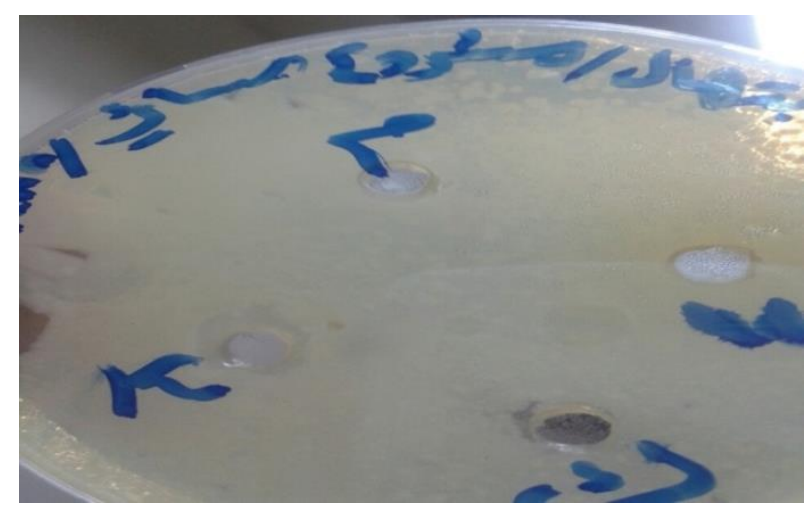

Fig.(4): Antibacterial activity of alcohol extract of Agaricus bisporus against Salmonella typhi.
Also the result shows that the two controls (water and ethanol) have no effect against the two tested bacteria. Result showed that no antibacterial activity of the aquous extract of A.bisporus. This results might be due to the solubility of substances that is responsible for the antibacterial action is more with certain solvent in compared to water. Results are in agreement with [9] who showed that ethanolic extract showed well antibacterial and antioxidant activities as compared to methanolic extract. Results are also in agreement with [7] since their results showed that the crude of mushroom revealed antibacterial properties to all tested bacteria. Extract aqueous showed the lowest inhibition of bacterial growth, while the extracts obtained from ethanol were exhibited the most effective influence against the tested bacteria followed by methanol and aceton. Özturk et al., [10] indicated that the methanol extract of wild strain of A.bisporus collected from Turkey displayed the ability to inhibit several G+ve bacteria more effectively than G-ve bacteria.

\section{Conclusion}

From the above results, it was concluded that ethanol extract showed good activity against S.typhi \&S. aureus as compared to aqueous extract. therefore A.bisporus is good for health and could be used as a source of natural antioxidant which is essential in hostile against disease and as possible food supplement or in therapeutic industry. Wild edible mushroom could be used as agent in the enlargement of new medications for the infection by bacteria. This study showed the antibacterial influence of mushroom differs depending on the bacterial type.

\section{References}

[1] Karaman I., Sahin F., Güllüce M., Ogutçü H., Sengül M., Adigüzel A., "Antimicrobial activity of aqueous and methanol extracts of Juniperus oxycedrus L", L. J. Ethnopharmacol, 85(2-3), 231 - 235, 2003.

[2[ Stamets P., "Growing gourmet and medicinal mushroom", Berkeley Ten Speed press. 45-49, 2000.

[3] Turkoglu A., Duru M.E., Mercan N., Kivrak I., Gezer K., "Antioxidant and antimicrobial activities of Laetiporus 
sulphureus (Bull.) Murill" Food Chem., 101: 267- 273, 2007.

[4] Dulger B., Ergul C.C., Gucin F., "Antimicrobial activity of the macrofungus Lepista nuda", Fitoterapia 73:695-697, 2002.

[5] Padmavathy M., Sumathy R., Manikandan N., Kumuthakalavalli R., "Antimicrobial activity of mushrooms against skin infection causing pathogens", Res. Biotechnol, 5(2), 22-26, 2014.

[6] Reis F.S., Pereira E., Barros L., Sousa M.J., Martins A., Ferreira ICFR, "Biomolecule profiles in inedible wild mushrooms with antioxidant value". Molecules 16(6) 4328-4338, 2011.

[7] Reid T., Kashangura C., Chidewe C., Albert Benhura M., and Mduluza T., "Antibacterial properties of wild edible and non-edible mushrooms found in Zimbabwe", African Journal of Microbiology Research, 10 (26), 977-984, 2016.

[8] Azoro C., "Antibacterial activities of crude extract of Azadirachita indica on Salmonella typhi", World Journal of Biotechnology, 3,347-351, 2002.

[9] Pandey A., Pandey A.K., Jamaluddin and Ritu Panjwani, "In Vitro Antioxidant and antibacterial Activity of Agaricus bisporus (button Mushroom)", Asian Journal of Biochemical and Pharmaceutical Research., 3(4), 51- 54,2013.

[10] Öztürk M., Duru M.E., Kivark S., Mercan-Doĝan N., Türkoglu A., özler M.A., "In vitro antioxidant anticholinesteras and antimicrobial activity studies on the three agaricus species with fatty acid compostion and iron contents,: acomparative study on the three most edible mushrooms", food chem toxicol., 49, 13531360, 2011. 